\title{
A estrutura do usufruto frente às possibilidades de sua aplicação
}

\section{The structure of the usufruct facing the possibilities of its application}

\author{
Manoel Pedro Ribas de Lima Correio \\ Mestre em Direito Constitucional pela UniBrasil \\ manoel@ribasdelima.com.br
}

\begin{abstract}
RESUMO
O presente estudo busca apreender a natureza jurídica do instituto do usufruto a partir da análise de todas as possibilidades de sua aplicação no cotidiano. Verificase que, pela análise de sua estrutura, o usufruto ultrapassa-se a condição de direito real. Tal colocação, assim positivada no Código Civil, tem provocado limitações na vida prática. Valendo-se de discussões práticas, observou-se a aplicabilidade do usufruto também a direitos obrigacionais. Percebe-se a necessidade de uma a revisão da lógica de sua vigência, pois se revela que o objeto do usufruto não é a coisa, tampouco a prestação, mas sim o direito. Conclui-se que o usufruto é um gravame a direito, seja qual natureza for este direito, e não como um direito propriamente dito.
\end{abstract}

Palavras-chave: Usufruto, gravame, direito real, direito pessoal, eficácia e vigência.

\begin{abstract}
The present study aims to apprehend the legal nature of the Institute of usufruct from examining all the possibilities of their application in practical life. By analyzing the structure of that institute, opened the possibility to overcome their status as real right. Exposed by the Civil Code, this view has caused limitations in its practical life. Relying on practical discussions, it was checked the applicability of usufruct also on the personal rights, what implied in the review of the logic of usufruct's liability. It reveals that the object of usufruct is not the thing, nor the duty, but the right. It was concluded that the usufruct is a burden on right of any kind, and not as a right in itself.
\end{abstract}

Keywords: Usufruct, burden, real right, personal right, factual and juridical practice.

\section{SUMÁRIO}

INTRODUÇÃO; 1. ESTRUTURA DO USUFRUTO; 2. SUPERAÇÃO DA DICOTOMIA DIREITO PESSOAL E DIREITO REAL; 3. A CARACTERIZAÇÃO DO USUFRUTO SOBRE CRÉDITO; 4. DO GRAVAME AO DIREITO; 5. CONCLUSÃO; REFERÊNCIAS.

\section{INTRODUÇÃO}

Com o decorrer do tempo, posicionamentos são sedimentados e aceitos dogmaticamente, sem discussão alguma. A admissão destes preceitos representa o primeiro 
passo para a construção de sistemas, os quais podem impor "novações" contrárias à natureza do que fora estabelecido. Portanto, a artificialidade que é o Direito, modernamente entendido com um sistema, normalmente esbarra nas possibilidades que se desdobram de sua própria realidade. Não que isto seja maligno, mas o é no caso do usufruto, instituto jurídico atropelado pela sistematização.

Segundo o direito positivo brasileiro, no sentido de ordenamentos estrangeiros, o usufruto aparece como um direito real sobre coisa alheia. Estando disposto no Título IV do Livro III (Do Direito das Coisas) do Código Civil, o usufruto é entendido como direito que recai sobre bem de outrem, sendo que bem significa coisa sobre a qual incide a propriedade (art. 1.390). Deste entendimento decorrem afirmações como àquela que vê o usufruto como poder transitório de exercício sobre coisa contraposta ao direito de propriedade, sendo para este uma limitação, e ainda que o que usufruto não ocupa a posição acessória à propriedade ${ }^{1}$.

Sobre sua contraposição à propriedade, os doutrinadores afirmam que o usufruto constitui-se em um direito ao uso e à fruição, elementos daquele instituto, sem, contudo, aparecer como modalidade. Posto isto, usufruto não seria acessório à propriedade, embora a existência desta the seja pressuposto ${ }^{2}$. Seriam como direitos paralelos, que, existiam sobre o mesmo objeto, não se comunicariam. 0 direito de propriedade estaria limitado, restando ao seu titular apenas o direito de dispor da coisa - único poder que o usufrutuário não deteria. Assim, apenas aos objetos (independentemente de sua natureza física) envoltos pela propriedade que se aplicaria o usufruto.

Pela transitoriedade, surge o consenso entre os civilistas de que os objetos sobre os quais recai o usufruto têm de ser perenes; que dure, em sua existência, o suficiente para superar o espaço de tempo da vida de uma pessoa. Para os efeitos do usufruto, na ideia de coisa, embora escapem à noção de direito real, incluem-se direitos de duração razoável, como ações de sociedades anônimas e direitos autorais. Por outro lado, os doutrinadores descartam do usufruto os direitos de fruição sobre bens consumíveis, sobre títulos de créditos, como ainda sobre direitos obrigacionais em geral.

\footnotetext{
${ }^{1}$ Ver VENOSA, Sílvio de Salvo. Direito Civil: direitos reais. $3^{\circ}$ ed. São Paulo: Atlas, 2003, p. 421 e SANTOS, J. M.Carvalho. Código Civil Brasileiro Interpretado. Vol. IX. $9^{\mathrm{a}}$ ed. Rio de Janeiro: Freitas Bastos, 1958, p. 330.

${ }^{2} \mathrm{O}$ fato de existir, no nosso ordenamento, o usufruto de bens da União por silvícolas não afasta esta tese. Embora o domínio de bens, seja móveis ou imóveis, pelo Estado não implicar em propriedade, segundo a doutrina brasileira, não significa que a União não tenha poder suficiente para ser cindido para outros institutos do Direito Civil. Sobre o usufruto por silvícolas, ver Lei $\mathrm{n}^{\circ} 6.001 / 1.973$, art. 41 , I.
} 
Deste raciocínio, que em verdade não se sucede apenas do posicionamento sistemático do usufruto no ordenamento jurídico, surgem limitações práticas. Sobre um título de crédito, embora haja disposição autorizadora neste sentido (C.Civil, art. 1395), segundo a doutrina não se poderia dizer que existe usufruto. E se existisse, recairia sobre o título, e não sobre a obrigação nele constituída. Não haveria usufruto de bem consumível dado que este tipo de coisa (logo, a propriedade sobre ela) se dissiparia em lapso tão pequeno que a existência da distinção entre usufruto e propriedade pareceria ser sem razão (a coisa se perderia antes que o proprietário pudesse reaver a plenitude de seu direito). E para escapar deste problema, sem resolvê-lo, a doutrina civilista moderna agarrou-se à figura do quase-usufruto, que representa a transferência da propriedade do objeto com o dever do adquirente de restituir, em objeto de mesma espécie ou em pecúnia, o alienante (Código Civil de 1.916, art. 726).

Ainda em razão deste posicionamento aparece o conflito quanto à caracterização do instituto a partir do seu exercício - o que é mais uma confusão do que um problema lógico. Pelas disposições de deveres e direitos entre usufrutuário e titular (como se nomeará o nu-proprietário daqui por diante), espúria é a negação da relação jurídica entre estas duas pessoas; uma relação que não é direito pessoal tampouco de direito real. Se essa relação fosse de direito pessoal, isto é, caracterizada pela relação em que um deve um determinado comportamento a outrem, como um tem o direito de que outro se comporte de certa maneira, existiria comodato ou, caso houvesse contraprestação, locação. Ora, aí haveria a negociação da posse, ou seja, o exercício sobre a coisa. Se a relação fosse puramente de direito real, ou seja, onde alguém tem o direitopoder sobre algo contra outrem, e onde esse outrem é vedado a intervir sobre tal poder, haveria enfiteuse. Aí, independentemente da distinção da extensão temporal entre os institutos, o enfiteuta tem plenos poderes sobre a coisa, diferentemente do usufrutuário.

Os erros do qual desencadeiam tantos problemas residem no conceito de direito [subjetivo], e não tanto na caracterização do usufruto como direito (uma mera questão de perspectiva). No momento em que se tem o direito como um dever reverso (Hans Kelsen) exigese a explicitação clara da relação jurídica e a maneira que ela se opera. Ou melhor, questionamse quem deve, quem tem o direito e sobre o que recai tal relação.

A exigência pela qual se manifesta a norma pressupõe necessariamente de uma relação. A relação creditícia, nascidas dos contratos, da responsabilidade civil e da lei não deixa dúvidas quanto a isto. Mas qual é a relação jurídica instituída pelo usufruto? Uma de direito real? Não, nos direitos reais, as relações são potenciais (talvez nunca venham a acontecer); no usufruto a relação entre o titular e o usufrutuário, embora limitadas aos casos previstos em lei, é certa. 
Como entender isto? E, ao mesmo tempo, como explicar a relação destes dois sujeitos com terceiros? Falta algo à explicação normativa? Afinal de contas, como se dá o exercício do direito do usufruto? E se o usufruto recai tanto em coisas quanto créditos, ou seja, sobre direitos? Como pode ser ele considerado um instituto de direito real, tão limitado quanto à sua aplicabilidade?

Errado é afirmar que a colocação do usufruto como direito real remete à sua origem. Pelo contrário, analisando a estrutura da relação jurídica através do raciocínio jurídico contemporâneo, percebe-se que o entendimento atual segue o desenvolvimento da visão normativista do Estado soberano. Já o usufruto remete ao final da república romana, época à qual a lei não era marcada pela noção de ordem.

Com efeito, uma abordagem positiva sobre o instituto do usufruto, ao menos em termos sistemáticos, não será capaz de satisfazer os questionamentos levantados. Uma postura como esta exige uma análise prévia sobre a propriedade, o que restringiria o estudo, senão o conduziria na contramão dos problemas levantados. As perguntas bases para a pesquisa foram formuladas a partir do cotidiano, tendo em mente todas as possibilidades e impedimentos que do usufruto se abrem. E neste sentido, buscou-se pelo usufruto não só como ele se apresenta, mas também a significação que dele se apreender da sua positivação no Direito.

Através da análise do instituto que é o usufruto, o qual, em verdade, é um gravame a um direito, necessitou averiguar a manifestação dos direitos civis. Constatou-se um potencial ao usufruto para além daquele ensinado pela doutrina - aproximando-nos a uma dimensão que extrapola um método dedutivo-histórico. Da conclusão da pesquisa, que motivou a redação deste artigo, estabelece-se uma proposta de entendimento, que escapa a visão dominante e que, como efeito, resgata características presente na concepção originária do instituto do usufruto.

\section{ESTRUTURA DO USUFRUTO}

Certo é dizer que usus fructus est ius alienis rebus utendi fruendi salva rerum substantia ${ }^{3}$. A validade deste conceito, firmado por Paulo, pretor romano, e preservado até nós pelas Institutas de Justiniano, é inquestionável depois de concebida a estrutura do usufruto.

Primeiramente, cabe dizer que o usufruto não se constitui em si um direito. Estritamente falando, todo direito, ainda que exposto à relação com outros direitos contidos no

3 "O usufruto é o direito de usar e gozar a coisa alheia, preservando a substância", tradução de DANTAS, Francisco Clementino San Tiago. Programa de Direito Civil III: direito das coisas. $2^{\circ}$. ed. Rio de Janeiro: Ed. Rio, 1981, p. 341. 
mesmo ordenamento (validade), não depende destas afinidades para sua vigência. É impróprio falar que exista direito sobre direito. 0 direito existe pelo simples fato de ser positivado, seja por qual modo for. 0 usufruto, por sua vez, depende de direito prévio para existir, o qual será chamado de direito originário. Este direto tem um titular próprio, pessoa necessariamente distinta daquele que detém o usufruto.

Por outro lado, o usufruto não representa o mero exercício fático deste direito originário. Ele existe no plano jurídico (est ius), se manifestando como a secção deste direito, do qual é resguardada apenas a própria titularidade (alienis rebus), em contraste à atribuição de faculdades e deveres ao usufrutuário que nada mais são que os poderes que o titular teria (utendi et fruendi). Ao usufrutuário incide a capacidade de oposição dos seus poderes para com outras pessoas, podendo estabelecer negócios como se titular do direito originário fosse (C.Civil, art. 1.393, segunda frase). Todavia, dito desta maneira, afirma-se que o usufrutuário tem o dever de manter intacta a titularidade anterior (salva rerum substantia), sem a qual seus próprios direitos perderiam existência. Prefere-se, assim, entender o usufruto como gravame a direito.

Como conteúdo do usufruto, diferentemente do direito stricto senso, existem relações jurídicas de diferentes "naturezas". Há necessariamente, de forma sinalagmática, o vínculo entre o titular e usufrutuário. 0 primeiro tem a prerrogativa de ver seu direito intocado tanto quanto tem o dever de transferir o poder sobre o objeto do direito originário e reconhecê-lo quando em mãos do usufrutuário. Todavia, o titular pode dispor do seu direito (alienando, cedendo, doado, etc.), desde que o próprio direito remanesça. 0 usufruto não nasce da pessoa do titular, mas sim ao direito, o qual é agravado ${ }^{4}$. 0 usufrutuário tem, neste vínculo, a prerrogativa de reivindicar para si os poderes atribuídos pelo direito originário ao titular, como tem o dever de zelar pela existência deste direito, o que implica na manutenção do objeto deste.

${ }^{4}$ DIREITO CIVIL. PENHORA SOBRE NUA-PROPRIEDADE DE IMÓVEL, GRAVADO COM USUFRUTO VITALíCIO. POSSIBILIDADE.

- Da interpretação conjunta dos arts. 524 e 713 do CC/16, fica evidente a opção do legislador pátrio em permitir a cisão, mesmo que temporária, dos direitos inerentes à propriedade: de um lado o direito de uso e gozo pelo usufrutuário, e de outro o direito de disposição e seqüela pelo nu-proprietário.

- A nua-propriedade pode ser objeto de penhora e alienação em hasta pública, ficando ressalvado o direito real de usufruto, inclusive após a arrematação ou a adjudicação, até que haja sua extinção.

Recurso especial não conhecido.

(REsp 925.687/DF, Rel. Ministra NANCY ANDRIGHI, TERCEIRA TURMA, julgado em 09/08/2007, DJ 17/09/2007 p. 275). 
Estabelecida tal relação, o usufrutuário tem o poder de participar de negócios com o objeto do direito originário, bem como dele se valer para si, independentemente do titular (C. Civil, art. 1.394 et seq.). Quando se fala de fruição e de aquisição dos frutos, em se tratando de usufruto, não se refere aos conceitos técnicos ${ }^{5}$; o usufrutuário tem o direito de todo proveito e produto que o direito originário possa disponibilizar. E como "sucessor" dos poderes oriundos do direito, e não do seu objeto, nada impede que o usufrutuário admita o uso fático da coisa em seu poder pelo titular, como ainda o usufrutuário pode transferir para terceiro esse exercício. Estas outras relações, sempre eventuais, podem ter natureza tanto de direito pessoal como de direito real conforme o objeto do direito originário.

Por outro lado, como o usufruto desdobra-se do direito em todas as possibilidades deste, o usufrutuário, em tese, também tem que arcar com todas as despesas decorrentes do direito originário (C. Civil, art. 1.403). A origem das despesas podem ser tanto aquelas oriundas da própria fruição do direito como as decorrentes da mera titularidade do direito, como impostos $^{6}$. Não responde o usufrutuário apenas por custas decorrentes de poderes que não estejam contidos no gravame.

Destacam-se, então, como sujeitos do usufruto o usufrutuário, o titular e eventuais terceiros. Da mesma forma que sobre o direito poderá haver várias pessoas na posição de titular, o gravame possibilita também essa pluralidade. Aparece aqui a figura do co-usufruto. Se o direito originário exige tão somente uma pessoa na posição de titular, apenas uma pessoa pode ocupar o lugar do usufrutuário. Os terceiros que venham a se vincular com o usufrutuário em razão do usufruto, em sua qualidade e número, variam sempre de acordo com a natureza do negócio estabelecido.

O usufrutuário pode recusar ao usufruto, desfazendo assim o seu liame com o titular. Porém the é impossível a disposição do gravame para terceiro (C. Civil, art. 1.393, primeira frase). A relação do usufruto, como decorre da existência de direito de outro, não permite que o usufrutuário transmita, como amplie, o gravame, dado que esta espécie de disposição não lhe é

\footnotetext{
${ }^{5}$ VIANA, Marco Aurélio da Silva. Comentários ao Novo Código Civil. vol. XVI. Rio de Janeiro: Forense, 2003, p. 639.

6 "...em tese, o sujeito passivo do IPTU é o proprietário e não o possuidor, a qualquer título [...] Ocorre que, em certas circunstâncias, a posse tem configuração jurídica de título próprio, de investidura do seu titular como se proprietário fosse. É o caso do usufrutuário que, como todos sabemos, tem a obrigação de proteger a coisa como se detivesse o domínio" (REsp 203.098/SP, Rel. Min. Carlos Alberto Menezes Direito, DJ 8.3.2000).
} 
legitima. Fica vedada também a penhora do usufruto (RT 797/274) ${ }^{7}$. Sendo um gravame, apenas o titular pode criar outro usufruto, se assim o direito possibilitar, ou criar novo usufruto, quando o anterior já estiver extinto. Como o próprio termo revela, ninguém pode agravar mais a posição do titular senão ele mesmo ${ }^{8}$. Em outras palavras, a posição de usufrutuário é personalíssima.

Sendo intransmissível, o gravame está, diferente do direito, vinculado à pessoa do usufrutuário. Assim, a permanência deste instituto tem como limite essencial a vida do sujeito que the detém. Morto o usufrutuário, necessariamente, e indiferentemente de eventuais condições, o usufruto se extingue. No caso do usufruto por pessoa jurídica, estipulado por lei é o prazo máximo de trinta anos para a vigência do gravame (C.Civil, art. 1.410, III). E falando de pessoa, impossível é o usufruto por coletividade sem personalidade jurídica, dado que não poderia ser estipulado um limite ao usufruto sem que alguém seja prejudicado9. Todavia, este obstáculo não impede a estipulação de condição resolutiva ao usufruto que possa anteceder o falecimento do usufrutuário (C.Civil, art. 1.410).

Desta mesma lição, impossível é a sucessão de usufruto, ou ainda, usufruto sucessivo ${ }^{10}$. Quando o usufruto é desfeito, pelas condições de sua existência ou pelas estabelecidas na sua constituição, o direito originário ganha plenitude, ficando desembaraçado deste ônus. Resgatado assim o direito do titular de reivindicar o objeto do direito através de declaração. A sucessão do usufruto, que fora previsto nas antigas Ordenações, não é cabível desde o Código Civil de 1916.

\footnotetext{
${ }^{7}$ Mas os frutos propiciados ao usufrutuário podem sim ser penhorados (CPC, art. 723, e Resp 242.031-SP), independentemente de intimação do titular (RJ 239/80), mas especificando, quando o usufruto recai sobre patrimônio, sobre qual bem o exercício fica limitação do exercício. NEGRÃO, Theotonio; GOUVÊA, José Roberto F. Código de Processo Civil e legislação processual em vigor. 39 ed. São Paulo: Saraiva, 2007 , p. 823 , nota art. 649:18. Contudo, extinto o usufruto durante o período estabelecido da penhora, este ônus deve ser desfeito, pois o titular não pode ser limitado em seu exercício. Na verdade, vislumbrada esta possibilidade inviabilizaria tal penhora não deve ser deferida (CPC, art. 722).

${ }^{8}$ Pode ser criado por juízo o usufruto sobre direito do qual o titular é executado, sendo o usufruto uma forma de adjudicação. Isso não caracteriza uma disposição do usufrutuário, embora sua vontade seja requisito para a imposição do ônus, mas sim a responsabilização patrimonial do titular (de outra forma seria transação). ASSIS, Araken de. Manual de processo de execução. $2^{a}$ ed. São Paulo: Editora Revista dos Tribunais, 1995, p. 635.

${ }^{9}$ Embora hoje se possa falar em entidades não personificadas, distintamente ao que pensava Pontes de Miranda, o usufruto, por ser personalíssimo, implica, primeiro, na indicação certa do seu titular e, em segundo, apesar de imaginar a aplicação da regra estipulada para o usufruto por pessoa jurídica, uma coletividade é formada por pessoas físicas incertas. Se uma pessoa, de boa-fé, passasse a integrar esta coletividade e fruir do bem, prejudicaria a estipulação de um termo final para o usufruto. Por isso a pluralidade, no usufruto, exige a identidade das pessoas. Ver MIRANDA, Pontes de. Tratado de Direito Privado: Parte especial; direito das coisas: usufruto. Uso. Habitação. Renda sobre imóvel. Tomo XIX, $2^{a}$ ed. Rio de Janeiro: Editor Borsoi, 1957, p. 21-22.

${ }^{10}$ Usualmente é distinguido o usufruto do fideicomisso em razão da sucessão de titularidade. Todavia, a diferença principal é que o usufruto é limite a propriedade (direito), enquanto o fideicomisso é propriedade limitada (ver C.Civil, art. 1.953).
} 
A retirada da sucessão não ocorreu por força das então novas normas de Direito Civil, sendo a vedação uma norma de ordem pública ${ }^{11}$, senão pela própria essência do usufruto, que não admite sua transmissibilidade. O que ocorria na vigência de normas que possibilitavam a transmissão do usufruto, como acontece ainda em ordenações estrangeiras, significa uma exceção às regras de usufruto.

Preciso é esclarecer que, frente às diferentes modalidades de usufruto, a coisa, objeto do direito originário, nunca é objeto imediato do usufruto. Embora seja conhecida a modalidade chamada de usufruto sobre direitos, em contraste ao usufruto de coisa corpórea, o que se varia aqui são as qualidades do objeto do direito. Mas quando se fala que um bem é gravado pelo usufruto; em realidade está se referindo ao direito que a ele está relacionado. 0 único reflexo fático que a coisa sofre é a substituição de seu possuidor. De outro prisma, talvez seja permitido dizer que sobre a coisa implicam dois institutos jurídicos, e não dois direitos.

A transformação da natureza do objeto do direito originário é vedada plenamente ao usufrutuário. O objeto não pertence ao usufrutuário; em sua posição, do objeto, como do direito, cabe apenas fruir de todas as possibilidades que ele the proporciona. E para garantir esta situação aparece a aplicação de caução, que, em verdade, não é obrigatória.

Desta forma, o direito, tendo como sua manifestação fática a positivação, seja por qual meio for, exige a traditio solenis, isto é, a formalização do usufruto de modo proporcional à existência jurídica do direito agravado. Se o direito está constituído em registro, o usufruto tem de ser registrado - situação do usufruto de propriedade sobre imóveis ou de empresa (C.Civil, art. 1.391, art. 1144, e art. 108). Se o direito está corporificado em uma cártula, deve estar expressa na cártula a existência de usufruto - como o caso do usufruto sobre ações (Lei $n^{\circ}$ 6.404/76, art. 40). Se o direito existe pela mera positivação legal, outra exigência não há senão a previsão do usufruto em lei; aqui seria o caso do usufruto constituído em direito sobre bem móvel (C.Civil, art. 107). Se o usufruto é imposto por decisão judicial, no caso da sua criação como forma de adjudicação, ele deve ser averbado no devido registro (Súmula STJ $n^{\circ} 375$ ). Certo é que sem ato paralelo ao meio pelo qual se manifesta o direito originário, haverá outro direito que não o usufruto, salvo o usufruto decorrente de lei - usufruto vidual e usufruto decorrente do

${ }^{11}$ MONTEIRO, Washington de Barros. Curso de Direito Civil: Direito das coisas. Vol. VI. $12^{\mathrm{a}}$ ed. São Paulo: Saraiva, 1973, p. 284. 
pátrio poder (Lei $\mathrm{n}^{\circ} 6.015 / 73$, art. 167, I, 7); como é certo que o registro assegura o gravame ao usufrutuário contra terceiros. ${ }^{12}$

Adianta-se aqui que é requisito para a constituição do usufruto a notificação do terceiro (devedor) quando se trata de usufruto de títulos de créditos ou de obrigações em geral, que não possuem registro para produção de efeitos contra terceiros, a fim de afastar o pagamento repetido.

Outra condição ao usufruto é, seguindo o raciocínio, a natureza do direito originário. Para que se crie o gravame, este título tem de ser alienável, posto a disposição do titular ao usufruto. Como dito acima, o gravame infiltra-se no direito, não na pessoa do seu titular. Consequentemente, a todo direito personalíssimo é inaplicável o usufruto.

Distante da condição anterior, o usufruto tem de ter expressão econômica, muito embora o direito ao qual se constitui pode não ter valor algum - o que é difícil de imaginar. Esta exigência surge do dever do usufrutuário em conservar o direito do titular, bem como o seu objeto(C.Civil, art. 1.400). Se não fosse estipulado valor, impossível seria uma eventual indenização. Tal valor, segundo Rodrigues, "alcança todo o valor econômico da coisa, compatível com a conservação da propriedade" ${ }^{13}$.

Por fim, aparece uma condição lógica, que impede a instituição do usufruto sobre direitos decorrentes dos próprios poderes atribuídos a ele. Por exemplo, é absurdo falar em usufruto de locação.

\section{Superação da dicotomia direito pessoal e direito real}

Traçadas as manifestações básicas do usufruto, passa-se aqui a perquirição sobre a natureza deste instituto. O tema gerou debates que se estenderam por longos períodos,

\footnotetext{
${ }^{12}$ DIREITO CIVIL E TRIBUTÁRIO - EXECUÇÃO FISCAL - BEM PENHORADO QUANDO JÁ CONSTITUÍDO USUFRUTO EM FAVOR DE TERCEIRO - ALIENAÇÃO JUDICIAL - EXTINÇÃO AUTOMÁTICA DO GRAVAME - IMPOSSIBILIDADE.

1. A garantia e os privilégios do crédito tributário, por força do art. 184 do CTN, referem-se apenas àqueles bens e direitos que efetivamente integram o patrimônio do devedor. Diante disso, não é possível a imediata extinção do usufruto, como mera consequencia da alienação judicial do bem penhorado em execução fiscal, quando, por ocasião da penhora, já havia usufruto instituído em favor de terceiros, devendo ser observado o disposto no art. 1.410 do Código Civil quanto à extinção do usufruto.

2. Recurso especial não provido.

(REsp 832.708/PR, Rel. Ministra ELIANA CALMON, SEGUNDA TURMA, julgado em 16/09/2008, DJe $21 / 10 / 2008)$

${ }^{13}$ RODRIGUES, Sílvio. Direito Civil: direito das coisas, v. 5. $27^{\text {a }}$ ed. São Paulo: Saraiva, 2002, p. 296.
} 
intensidade suficiente para motivar até hoje uma explicação, ainda que breve, sobre o tema pelos doutrinadores. Esta disputa tem como causa efetiva o exercício do usufruto "no sentido da percepção efetiva ou material da utilização da coisa" ${ }^{14}$. A partir do momento em que o usufrutuário pode ceder o exercício, surgindo a figura do terceiro, vinculado de tal maneira que não implica em relação de direito real, perde-se o foco sobre qual relação é a principal.

Para não se limitar à interpretação do conceito moderna, que faz referência à coisa, antes é preciso dizer que a distinção de direito pessoal e direito real não é totalmente irrelevante. De fato, quando vigentes, as duas modalidades de direito civil possuem a mesma estrutura. Ambas constituem relações interpessoais em que pólos são formados a partir da contraposição de dever e prerrogativas; porém a distinção entre direitos pessoais e reais não se dá apenas pela ênfase no objeto e na espécie deste ${ }^{15}$ Sem dúvidas, desta ênfase aparecem efeitos diferentes. Dos direitos reais decorre a tutela judicial sobre a coisa, suscetível desde o momento da aquisição, através de pedido reivindicatório - mais especificamente, o de sequestro. Os direitos pessoais, por sua vez, só são tuteláveis com a constituição da mora, decorrente da inadimplência. Isto é impossível ao direito real. Quando se fala de mora na tutela de direito real em verdade trata-se de responsabilidade civil (direito pessoal), acarretado pela presença de ato ilícito.

Dantas fala que o usufruto seria direito real dado que o usufrutuário, "para defender-se no seu direito" quando frustrado na posse sobre o objeto do direito originário, "dispõe igualmente dos meios petitórios e possessórios". Já no caso da locação, um direito pessoal, o locatário teria apenas o meio "para que este [o locatário] lhe faça entrega da coisa ou lhe assegure o uso tranqüilo, ou, se não puder ou não quiser realizar uma dessas providências, para que lhe pague perdas e danos" ${ }^{16}$. Apesar da sua perspicácia, sua premissa é equivocada. Ele diz que "o que existe é o próprio exercício, [ou seja] é a faculdade que se tem de explorá-la [a coisa] como melhor for conveniente" ${ }^{17}$. Entretanto, frustrado o gozo sobre o objeto do direito originário, ao usufrutuário remanesce intacto o objeto do usufruto, que é o direito. Se a própria

\footnotetext{
${ }^{14}$ PEREIRA, Caio Mário da Silva. Instituições de Direito Civil: posse, propriedade, direitos reais de fruição, garantia e aquisição. Vol. IV. $9^{a}$ ed. Rio de Janeiro: Forense, 1992, p. 202. Ver referência a Marty et Raynaud no mesmo livro, na p. 196.

${ }^{15}$ Ao contrário do que diz RIZZARDO, Arnaldo. Contratos, Vol. I. Rio de Janeiro: Aied Ed., 1988, p. 12.

${ }^{16}$ DANTAS, Francisco Clementino San Tiago. Programa de Direito Civil III: direito das coisas. $2^{\circ}$. Ed. Rio de Janeiro: Ed. Rio, 1981, p. 343.

${ }^{17}$ Ibid., p. 342.
} 
coisa fosse o objeto do usufruto, impossível seria a cessão do exercício sobre ela pelo usufrutuário para terceiro.

Constituído o usufruto, o usufrutuário tem em suas mãos as mesmas possibilidades de tutela decorrente do direito dado em usufruto. Ora, na tutela é que aparece o caso manifesto de participação de terceiro no vínculo do usufruto, como também a forma em que se desenrola o liame entre usufrutuário e titular. O direito originário revela qual regime se aplicará ao usufruto. Se recair sobre direito real, evidentemente terá o usufrutuário o direito de reivindicar a coisa. Se recair sobre direito de pessoal, o usufrutuário poderá exigir o crédito.

Ainda assim, o poder de exercício sobre o objeto de direito, tanto quanto o poder de cedê-lo para terceiro, é também indicação sobre qual regime dirigirá as relações do usufruto. Incerta é a afirmação de Bevilàcqua, quando diz "Aquele que exerce o usufruto, por cessão do usufrutuário, não exerce direito real, de usufruto, que continua a ser do usufrutuário", posta de tal forma que não poderia existir sobre o mesmo objeto dois direitos reais sobre coisa alheia, limitando o usufrutuário a ceder apenas na modalidade de direito obrigacional (locação, comodato, etc. $)^{18}$. 0 usufrutuário que cede o exercício, the propiciado quando o direito originário é direito real, pode estabelecer tanto direito pessoal, como a locação ${ }^{19}$, como direito real, no caso da superfície e da servidão (que recaem direitamente sobre a coisa).

Esta modulação é bem mais limitada no caso em que o direito usufruído é direito pessoal. A princípio, no usufruto sobre crédito, o único terceiro que pode aparecer é o próprio devedor originário. Aqui não há nada o que ceder, pois é própria relação originária que está em jogo. Já quando o usufruto recai sobre ações de sociedades anônimas ou sobre apólices, a figura do terceiro pode aparecer no papel do administrador. A renda sobre juros e dividendos aí, que representa a fruição, não é comprometida, tampouco o direito, pois os papeis recebidos permanecem em nome do titular. Ou seja, quando o usufruto só possibilita as constituições de relações obrigacionais com terceiros, o direito originário certamente trata-se de direito pessoal.

Frisa-se que estas relações secundárias em relação ao usufruto só podem ter como objeto imediato o objeto do direito, não o próprio direito.

Por fim, o regime do direito originário gera efeitos sobre o próprio vínculo entre titular e usufrutuário. No usufruto de direito real, o usufrutuário pode reivindicar do titular a coisa, o

\footnotetext{
${ }^{18}$ BEVILÀCQUA, Clóvis. Direito das Coisas, vol. 1. $4^{\mathrm{a}}$ ed. Rio de Janeiro: Revista Forense, 1956, p. 301.

19 A permanência do locador sobre o bem contra a vontade do proprietário, privilegiada pela Lei do inquilinato, explica-se antes pelos princípios da boa-fé e da continuidade contratual do que qualquer aproximação ao instituto do usufruto. Ver RT 180/680.
} 
que não há no usufruto de direito pessoal. Por outro lado, no último caso o usufrutuário pode restar inadimplente diante do titular. Recebido o crédito, independentemente do vencimento em relação ao devedor, o usufrutuário tem o dever de repassar o valor da relação principal ao titular - ao usufrutuário resta apenas os acessórios, entendidos como frutos do crédito. Se o pagamento não for revertido ao titular, então a inadimplência do usufrutuário é flagrante.

Sendo assim, não se pode falar de autonomia do usufruto ao direito originário. 0 que existe é a autonomia do exercício do usufruto pelo usufrutuário em relação ao titular. Outra conclusão é que o usufruto se antecipa logicamente da classificação de direito real ou pessoal, reforçando a interpretação aqui proposta.

\section{A caracterização do usufruto sobre crédito}

Embora já apontado as razões para ver o usufruto como um gravame a direito, antes de qualquer classificação que este direito possa ter, é preciso esclarecer como acontece o usufruto sobre direito pessoal. Dado a posição da doutrina, esta análise foi deixada de lado, sendo esta situação de difícil visualização para aqueles que já estão acostumados a ver no usufruto um direito real - como foi para quem aqui escreve. Com o intuito de facilitar a compreensão, será utilizado o debate, presente na RT 512, entre os juristas Moacyr Amaral Santos, ex-ministro do STF, e Modesto Carvalhosa, então professor adjunto da USP, que versa sobre usufruto de ações ao portador.

Emitindo pareceres opostos, defendendo claramente partes diversas, estes doutrinadores discutiam a validade de votos proferidos pelo titular de ações gravadas por usufruto. Estas ações eram, em verdade, títulos ao portador. O que chama atenção neste debate é o modo de colocação da natureza do usufruto e a indicação do seu objeto.

Santos, a fim de demonstrar a invalidade dos votos proferidos pelo titular, afirmou que "tais ações, como a dos títulos ao portador em geral, os documentos que as representam, como 'res' se submetem ao regime do Direito das Coisas" ${ }^{20}$. Conseguintemente ele declara que "por serem coisas móveis corpóreas, os títulos ao portador, integrativos e representativos de ações ao portador, podem ser objeto de direitos reais de garantia, em favor de terceiros, como o penhor, o usufruto, o fideicomisso, cuja disciplina legal [...] se norteará pelo Direito comum".

${ }^{20}$ SANTOS, Moacyr Amaral. Usufruto de ações ao portador; in: Revista dos Tribunais. Vol. 512. São Paulo: Editora Revista dos Tribunais, 1978, p. 46. 
Contudo, dada a ambulatoriedade dos títulos ao portador, de ampla cessão para terceiros, ele diz que "o ato constitutivo do usufruto transfere ao usufrutuário a propriedade das ações usufruidas [...] visto que as ações ao portador são 'circuláveis pela simples tradição manual, seu usufruto se converte em quase-usufruto" ${ }^{21}$. Conclui ele assim que os votos do titular não eram válidos porque a titularidade seria do usufrutuário.

Por outro lado, Carvalhosa, com o intuito de firmar a validade de tais votos, afirma que o usufruto daquele título ao portador não produziria efeitos para terceiros. De fato, aparentemente não haveria como existir averbação do gravame neste caso, pois o certificado da ação, que ficaria em mãos do portador (sócio), é instrumento para o exercício dos direitos daí decorrentes. Ou seja, impossível distinguir “o nu-proprietário do usufrutuário, pois a sociedade é obrigada a reconhecer a qualidade plena de proprietário a quem seja o detentor do certificado, não podendo argüir qualquer restrição ao exercício daqueles direitos”22.

Ambos negam a aplicação do usufruto sobre direitos obrigacionais, mas discordam sobre o fundamento. 0 primeiro entende que o usufruto recai apenas sobre bens duráveis, e não contingentes, como seriam tais títulos diante da facilidade de sua cessão. 0 segundo, contudo, entende que o usufruto recai sobre o direito, mas que o exercício tem de ser separável da mera vigência, como também que o gravame possa ser oponível a terceiros.

Moacyr Amaral Santos está errado, porque o usufruto não é, em si, direito, e sim gravame. Sendo gravame, não pode recair sobre a coisa, mas sobre o direito à coisa. No caso do título de crédito, o usufruto cai sobre o crédito, que é um direito, e não propriamente sobre o seu instrumento.

Deve-se esclarecer que o título não apenas corporifica o direito, sendo sua prova, mas antes é a própria existência do direito. Por isso, em regra, quem tem a posse do título ao portador tem o direito neste prescrito. Porém, existindo o usufruto, apesar de não precisar ser instrumentalizado, a posse não significa a titularidade do direito. Demonstrado o usufruto, o usufrutuário deve prestar contas do direito ao seu titular. A diferença é vital, pois assim não há transferência do crédito, como ele concluiu. Não obstante o título ao portador, o devedor do crédito deve ser cientificado, através de interpelação, do usufruto - isso acontece porque, no momento da instituição do usufruto, a pessoa do credor é identificada e consolidada, perdendo o título a plenitude de sua ambulatoriedade (capacidade de cessão do crédito, que dependente

\footnotetext{
${ }^{21}$ Ibid., 1978, p. 46-47.

${ }^{22}$ CARVALHOSA, Modesto. Usufruto de ações ao portador [resposta à Moacyr Amaral Santos]; in: : Revista dos Tribunais. Vol. 512. São Paulo: Editora Revista dos Tribunais, 1978, p. 81.
} 
exclusivamente do titular, não do usufrutuário), e ainda sobre a legitimidade processual para tutela do direito, que é tanto do titular quanto do usufrutuário.

O gozo das ações pelo usufrutuário, que representa a apropriação dos dividendos, não acontece em razão da apropriação do título. 0 gravame que é o usufruto representa a repartição do direito originário: de um lado a titularidade, de outro o gravame, o qual carrega consigo as atribuições dadas por aquele direito. Pontes de Miranda, por exemplo, equivoca-se quando fala que "A atividade do proprietário vai até onde encontra a restrição pessoal ou real. Não se trata de limitação, porque ainda onde o usufruto é de origem legal, a lei não limita o direito de propriedade, - legalmente lhe restringe o conteúdo, o exercício" ${ }^{23}$. A preocupação de Pontes de Miranda, presente na última oração, era, antes de tudo, distinguir usufruto de propriedade, não se aprofundando na natureza do instituto dentro do Direito Civil. No seu livro, a condição de direito real do usufruto é adotada, até ai, dogmaticamente. Com isto restou contraditória sua afirmação de que "O usufruto é direito subjetivo" ${ }^{24}$. Ele está certo aqui, mas porque o usufruto não recai sobre a coisa e seu exercício, mas sobre o direito de exercício.

Carvalhosa, embora consciente desta diferenciação e da decorrência da condição do usufruto em relação ao direito originário, trocou o regime jurídico aplicado ao usufruto, apegando-se ao direito pessoal no lugar do real. Ele antecipou as vestes de direito pessoal do usufruto como sua própria condição. Isso implica na desconsideração do usufruto, tanto quanto na tese de Santos, mas com efeito oposto.

Para ele os direitos de exercício do usufruto permaneceriam com o titular, dado que o usufruto não produziu efeitos contra terceiros. Isto vem evidenciar o erro de encaixar o usufruto em alguma parte especial do direito privado, que é um erro, pois, como gravame, ele se rege pela lógica geral do Direito Privado. "Sem dúvidas", como fala Carvalho Santos, "o usufrutuário deve notificar ao devedor do crédito o seu direito de usufrutuário, para que ele the pague os juros e, no vencimento, o capital, sob pena de duplo pagamento"25. Entretanto, se alguém tem

\footnotetext{
${ }^{23}$ MIRANDA, Pontes de. Tratado de Direito Privado: Parte especial; direito das coisas: usufruto. Uso. Habitação. Renda sobre imóvel. Tomo XIX, $2^{\text {a }}$ ed. Rio de Janeiro: Editor Borsoi, 1957, p. 08. Gomes distingue o usufruto de crédito do usufruto de título por uma razão diferente. Da leitura do seu artigo entende-se que o usufruto de título seria diferente dos de créditos pela imediata exigibilidade deste último, ou seja, pelo lapso temporal de sua existência. GOMES, Orlando. Usufruto de direito; in: Direito privado: novos aspectos. Rio de Janeiro: Freitas Bastos, 1961, p. 162. Mas todo direito, até mesmo contraposto ao dever continuado indeterminadamente, como a propriedade, terá um fim. Logo, o quase usufruto ou usufruto impróprio, indicado pela sua fluidez, é um erro.

${ }^{24}$ MIRANDA, Pontes de. op.cit., p. 09.

${ }^{25}$ SANTOS, J. M.Carvalho. Código Civil Brasileiro Interpretado. Vol. IX. 9a ed. Rio de Janeiro: Freitas Bastos, 1958, p. 382.
} 
direito a algo frente outra pessoa determinada, o direito recai sobre a obrigação do devedor (efeitos inter partes), o que não significa que o direito não existia e vigia em relação à terceiro. Logo, o usufruto, quando recai sobre direito de crédito, gera efeitos negativos quanto a terceiros, impedindo, no mínimo, a prática de cessão (ver Lei n 4.728/1965, art. 35).

Mas Carvalhosa está certo quando diz “Com efeito, o direito do acionista [usufrutuário] de participar nas assembléias decorre da sua legitimidade e não da sua titularidade; decorre da posse (em que, por seu turno, assenta a presunção de propriedade), não da propriedade, embora possa, como vimos, ser combatida a presunção decorrente da posse" ${ }^{26}$. A legitimidade do titular, neste caso, decorre de disposição específica de lei, que disponibiliza o voto a ele (Dec. Lei $n^{\circ} 2.627 / 40$, $\$ 2^{\circ}$ do art. 91 à época, e o atual Lei $n^{\circ}$ 6.404/76, art. 114); contudo, esta legitimidade não reside apenas no fato de ele ser titular, ou ainda na ausência de formalização do usufruto, mas antes por ser o possuidor autorizado pelo usufrutuário ${ }^{27}$.

O caso das ações é uma exceção. Nas demais relações obrigacionais, ocorrendo a interpelação, o usufrutuário tem o direito ao amplo exercício atribuído pelo direito. Em outras palavras, cabe ao usufrutuário exigir o crédito.

0 próximo, e mais profundo, problema do usufruto de direito pessoal é questão da confusão entre seu exercício e a titularidade do direito. Sua origem reside no fato de que o exercício (ou seja, exigido o crédito e, havendo pagamento, prestada a quitação) o direito pessoal se esgota. E, principalmente no caso dos títulos de créditos, onde a titularidade estaria a princípio no possuidor da cártula, aquele que recebe o valor confunde-se com a figura do credor. Plausível é o questionamento, pois a sujeição é específica, recaindo sobre as pessoas que constituem os sujeitos e sobre as condutas determinadas, sem constituir vínculo necessário à coisa (jus ad rem), como no direito real. Tecnicamente falando, a responsabilidade é pessoal. São fulano e sicrano que fazem parte da relação; ninguém mais a não ser a eles que a obrigação se limita. 0 conteúdo da obrigação esgota-se na dicotomia dever/direito.

Para desamarrar esse nó, deve-se resgatar a noção de conteúdo da obrigação. Seu conteúdo é o dever e o correspondente direito existente na obrigação, ou seja, ele é a capacidade de exigir de alguém que faça ou não faça (uma conduta positiva ou negativa) como também o dever de outro em cumprir com aquela cobrança.

${ }^{26}$ CARVALHOSA, Modesto. Usufruto de ações ao portador [resposta à Moacyr Amaral Santos]; in: : Revista dos Tribunais. Vol. 512. São Paulo: Editora Revista dos Tribunais, 1978, p. 82.

${ }^{27}$ Art. 114. 0 direito de voto da ação gravada com usufruto, se não for regulado no ato de constituição do gravame, somente poderá ser exercido mediante prévio acordo entre o proprietário e o usufrutuário. 
A prestação possui dois momentos dentro da obrigação. 0 primeiro, chamado de debitum, corresponde ao direito à prática do comportamento estabelecido, sendo imediato em relação à obrigação. O segundo momento é a obligatio, significando a exigibilidade e a transferência de capital de um sujeito para outro. A distinção decorre do Direito Romano, onde obligatio era a relação onde a pessoa do devedor era constrangida. Hoje, por outro lado, é deste momento que decorre a responsabilidade patrimonial do devedor, o que quer dizer que, se não cumprindo espontaneamente a obrigação, pode o credor exigir do Estado a apropriação e liquidação dos bens do devedor para a satisfação do crédito (CPC, art. 591).

Assim, quando se fala da obligatio, seja ela decorrente do inadimplemento da obrigação ou resultante da responsabilidade civil por ato ilícito, o titular tem o direito de ver seu crédito reconhecido pelo Estado e, posteriormente, ter satisfeito seu crédito pelo devedor. Com a obligatio, possibilitando a intervenção do Estado, como no processo de execução, e também na prestação espontânea do sujeito passivo da obrigação, o direito civil se manifesta em termos de meios (o comportamento, ou o processo, a penhora, a adjudicação, etc.) e fins (satisfação do crédito).

Antes de continuar é preciso advertir sobre estes dois momentos. Primeiro, debitum e obligatio não existem necessariamente uma com a outra. O debitum pode existir sozinho nas chamadas obrigações naturais (C. Civil, art. 880), como também na dívida prescrita, que possui sim relevância jurídica. Segundo, a responsabilidade patrimonial não é a mesma coisa que obligatio. Obligatio correspondem ao dever de transferência de riquezas (igual ao direito de exigir), responsabilidade patrimonial é o direito do Estado em atacar o patrimônio do devedor, e não meramente a exigibilidade do credor. Assim, o cumprimento espontâneo da obrigação não lhe nega a obligatio, senão afasta a possibilidade de intervenção do Estado. Terceiro, quando o debitum e obligatio não coexistem necessariamente uma com o outro, a primeira vista parece não existir relação jurídica. Certo é dizer que não existe obligatio sem debitum. Mas isto não vale para o contrário. Nas dívidas prescritas, onde ainda existe o dever, a obligatio perdeu-se, não obstante remanescer a relação jurídica. Assim, a existência apenas do debitum tornaria a obrigação imperfeita, mas não inexistente.

A expressão que esclarece o usufruto de direito pessoal é aquela que identifica a titularidade do direito com o debitum, representando a própria relação jurídica e a vigência do direito, e a atribuição de poderes com a obligatio. Com efeito, cabe ao usufrutuário exigir o pagamento, dar quitação, e se apropriar dos acessórios (juros, tanto remuneratórios quanto moratórios, e multas); ao titular resta o direito ao valor nominal do crédito (RT 101/436). 
O que realmente é impossível no usufruto de direito pessoal, em regra, é o usufrutuário ceder o exercício do direito, pois é o exercício desta modalidade (obligatio) que reveste e preenche o usufruto, como dito anteriormente. Esta vedação, todavia, não retira do titular o poder ceder o seu direito, desde que cumpridas as formalidades exigidas.

Chama-se a atenção agora para a possibilidade de investimento de crédito usufruído. Muitos pensam que, entregue valor corporificado em título de crédito ao usufrutuário, este poderia aplicá-lo em investimentos, a fim de obter meios para a produção de frutos. Todavia, este uso implica na mera entrega de valores para outrem, o que é mútuo. Não se pode confundir o usufruto de direito de crédito com mútuo. Se o título é entendido como simples pecúnia, a figura do devedor é indiferente, não podendo existir usufruto, pois o usufrutuário não tem de quem cobrar. Além disto, estes valores ficam submissos ao interesse e responsabilidade de quem recebeu. Não há restrição ao mutuário.

Por fim, na prática, titular e usufrutuário possuem legitimidade processual para cobrar o devedor, da mesma forma que ambos têm legitimidade para reivindicar, no usufruto de direito real, a coisa de terceiro que a possua injustamente. Mas, como a pretensão de cada um nasce na violação do direito, no caso das relações obrigacionais o interesse processual depende do inadimplemento (C.Civil, art. 189). Vale lembrar que a pretensão não é elemento essencial da obrigação porque ela é potencial, ou seja, o cumprimento espontâneo da obrigação pelos sujeitos não gera pretensão; mas sem dúvida, a pretensão é um efeito necessário da mora. E neste mesmo raciocínio, se o usufrutuário não repassar o valor do principal para o titular, este não pode exigir do devedor; em compensação, aí é o usufrutuário que responde por mora (sobre o principal, evidentemente).

\section{Do gravame ao direito}

Visto a manifestação do usufruto de direito pessoal, fica superada qualquer discussão sobre o usufruto de direito sobre coisas perecíveis (chamado de quase-usufruto). Estas coisas, ainda que não fungíveis, são substituíveis por outras de igual qualidade, não prejudicando o vínculo criado pelo usufruto. De todo modo, não há direito que se perpetue eternamente ou que 
não corra risco de desaparecimento durante a vigência do usufruto. Não existe razão de ser para o impedimento do gravame de direito que tem como objeto coisa fugaz ${ }^{28}$.

O importante é a possibilidade de gravar direitos, e esta questão nos remete direitamente à manifestação fática dos direitos. Gravame é ônus transitório ao direito originário, que cerceia do titular originário parcela das prerrogativas the atribuídas e que cede privilégios ao titular do gravame. $\mathrm{E}$, enquanto ônus imediato, como foi visto, o gravame deve acompanhar o direito.

Foi firmado no início que o Direito é uma artificialidade, criada pelos homens tanto para a proteção de suas relações (intersubjetivas) quanto para salvaguardar o próprio indivíduo e seus interesses. Estas criações, que atribui a uma pessoa um poder, poder a partir do qual este sujeito se vincula aos outros, são os direitos, os quais têm de ser entendidos um independentemente dos outros.

Por outro lado, se estes direitos fossem entendidos como ordens, na esteira da perspectiva normativista, não pode existir gravames ${ }^{29}$. Ordens não podem ser gravadas, apenas as coisas. Aí está a razão para que os modernos imaginassem que o usufruto recairia sobre a coisa, e, consequentemente, limitasse o gravame aos objetos dos direitos reais. A limitação fora tão fortemente fixada na mente dos civilistas que Orlando Gomes, buscando explicar o usufruto de direitos autorais, foi obrigado a entender a própria manifestação dos direitos como coisas ${ }^{30}$.

Mas Gomes, com sua pesquisa, abriu caminhos para a compreensão do usufruto. Ora, nem tudo o que é negociado são propriedades (coisas), mas os próprios direitos, os próprios títulos. Juridicamente falando, o objeto imediato de toda relação jurídica é um direito. Ainda que toda relação jurídica possua um objeto (coisa, seja material ou não), é antes o direito sobre essa coisa que é posto entre as partes. Conforme a direção tomada pela relação jurídica, ela encaminha-se ou para o regime de direito pessoal ou para o regime de direito real.

Isto ficou evidente quando o processo de apropriação se desvinculou da materialidade dos objetos dos direitos, ganhando maior fluidez. No decorrer dos dois últimos séculos, o mercado buscou a desmaterialização do direito. Com a função primordial e superar a limitação

\footnotetext{
${ }^{28}$ Só se estaria autorizado a falar sobre quase-usufruto na vigência do art. 726 do Código Civil de 1.916. Como não existe correspondente no atual Código, espúria é qualquer tentativa de resgatá-lo.

${ }^{29}$ Aí direitos civis seriam "direito subjetivo, abrangendo o poder de ação contido na norma, a faculdade de exercer em favor do indivíduo o comando emandado do Estado, definindo-se ius est facultas agendi", como disse PEREIRA, Caio Mário da Silva. Instituições de Direito Civil. Vol. 1. 10a ed. Rio de Janeiro: Forense, 1987, p. 11.

30 GOMES, Orlando. Usufruto de direito; in: Direito privado: novos aspectos. Rio de Janeiro: Freitas Bastos, 1961, p. 162.
} 
do objeto aos sujeitos (como estava construído o Code napoleônico), dilui-se as "coisas" das relações mercantis para a forma mais abstrata possível a fim de que o próprio negócio servisse como riqueza, ao invés de ser instrumento de transferência de riquezas (quanto mais imobilizado é o direito, vinculando-o aos objetos ou as pessoas, mais forte é a instituição que o tutela; por outro lado, se mais fluente for as riquezas, mais forte é o mercado). Embora a crise no final do ano de 2.008, créditos e ações ainda são os principais objetos negociados (criando um mercado virtual). Com isso se apreende que é o próprio direito (a algo), e não este algo, que é objeto dos negócios jurídicos.

Isto também se aplica à quase todas as relações de direito real. 0 exemplo mais prático é o requerimento do possuidor indireto de tutela do exercício sobre bem que está em posse de outrem, e ainda os direitos reais de garantia, que não recaem sobre o exercício, mas sobre o direito de propriedade. Enfim, direitos, ainda que estejam corporificados em documento próprio, não são propriamente coisas.

Mas uma característica pode ser atribuída aos direitos que os aproxima da idéia de coisa $^{31}$. Para que existam os poderes do titular, é preciso que exista algo em que ele se funda. Ele é sempre vinculado a um sujeito, ainda que apenas determinável, e não necessariamente a uma relação específica. Juridicamente, toda relação acontece entre pessoas. Mas a titularidade do direito não depende da existência imediata da relação, sendo esta potencial. Ou, ainda pode se dizer, mesmo que faticamente isso seja impróprio, que toda titularidade implica em uma relação erga omnes. Por outro lado, o direito só ganha relevância quando inserido em uma relação. Em outras palavras, a vigência de cada direito é autônoma em relação aos demais, mas a manifestação das relações jurídicas não impede que direitos sejam vinculados - por isso o usufruto não é propriamente um direito.

\footnotetext{
${ }^{31}$ Neste ponto aproveita-se para declarar a superioridade da estrutura das normas de direitos reais em relação as de direito pessoal. As normas de direito real são conceituais, criando limites a intenção dos particulares e abertura à liberdade de fato. As normas de direito pessoal, apenas do poder dos particulares de afastá-las, são expressas de forma imperativa. 0 primeiro efeito da diferença é a abertura da primeira ao juízo reflexivo para o julgador, pois a desconformidade do fato ao instituto não significa imediatamente um ilícito. Já a imperatividade torna o julgador um aplicar imediato da norma, dado que, agindo de modo contrário ao expresso, caracterizado está o ilícito. 0 mesmo efeito tem-se sobre os particulares. E sem dívidas é mais estreita a compreensão da segunda, pois se exige do cidadão conformidade de sua ação, para que seja válida, à Lei, e, para isso, as normas imperativas são de difícil compreensão, restando aos doutrinadores (que são lidos apenas pelos juristas, e não pelos cidadãos) esclarecerem a norma.
} 
Vistos que os direitos civis não são coisas no sentido de bem, mas possuem existência fática, eles só podem ser títulos - existente por uma conjugação de inter-esse ${ }^{32}$, com validade assegurada por uma instituição (tribunal).

Aí não se pode conhecer a distinção entre direito objetivo, que seria o corpo do direito, e direito subjetivo, a relação de dever. Passa a ser impossível esta divisão, pois a evidência destes conceitos só acontece quando norma e direito são identificados. De fato, toda relação jurídica manifesta-se no dever de alguém. Mas os direitos civis não decorrem de uma ordem. 0 direito é um poder, uma potestas, uma possibilidade entregue às mãos de uma pessoa (aqui está a razão da disponibilidade destas normas de direito privado pelos particulares). Toda disposição teleológica da norma se dissolve na inércia do titular. Estes títulos se aproximam aos bills ${ }^{33}$. Estatuído, em razão do direito, o bill voltava-se contra quem ofende ou se direciona àquele que deve, sempre com relações específicas. Estes deveres decorrem, faticamente, do direito civil sob titularidade de uma pessoa, para a qual cabe decidir que destino o dever tomará.

Só assim a liberdade dos cidadãos seria plena. Ora, os direitos enquanto direitos subjetivos só têm papel negativo, pois depende não só do indivíduo, mas, antes de tudo, do Estado soberano que the concede. Por outro lado, direitos como títulos implicam, antes de tudo, na responsabilidade do titular como dos participantes da comunidade, por suas relações (no limite à discordância), a criação de novos direitos e a tutela dos já existentes - Hominum causa omne ius constitutum est (Digesto, Livro I, Tit. V, fr. 1). 0 gravame, ônus criado ao direito em razão destas relações, com exceção dos casos de ordem pública, é manifestação de liberdade tanto do titular quanto, para este estudo, do usufrutuário.

\section{CONCLUSÃO}

Em sua origem, em Roma, o usufruto foi instituído para favorecer todos aqueles incapazes de figurar como herdeiros (como eram os celibatários). Impedidos a serem titulares, para estes foram outorgados o direito de uso de parte do patrimônio deixado, assegurando a sua sobrevivência. Constituía este patrimônio tanto direitos sobre bens imóveis quanto direitos sobre

\footnotetext{
${ }^{32}$ ARENDT, Hannah. A condição humana. 10. ed. Rio de Janeiro: Forense Universitária, 2003, p. 195.

${ }^{33}$ Sobre os bills, conferir relato de MONTESQUIEU. O espírito das leis. São Paulo: Martins Fontes, 1993, p. 219 e de BURKE, Edmund. Reflection on the Revolution in France. New Haven: Yale University Press, p. 14.
} 
coisas consumíveis e dinheiro, o que não impossibilitava o usufruto. Nestes dois últimos casos, satisfazia-se a salvaguarda do direito através da restituição ${ }^{34}$.

0 entendimento do usufruto, de forma tal que possibilite o exercício do usufrutuário sobre qualquer espécie de direito, foi re-construído aqui. Porém, não se pode falar propriamente em um resgate, pois isto é impossível quando o passado está perdido. Pontes de Miranda está certo, a razão da antiguidade, que alimentavam suas regras do usufruto, não se aplica hoje ${ }^{35}$. Por isso a proposta trazida aqui não pode ser entendida como uma nostalgia, muito comum entre os publicistas.

A compreensão do instituto do usufruto como foi esplanada aqui é totalmente aplicável ao ordenamento vigente, desde que o inciso IV do art. 1.225, que dispõe o usufruto como um direito real, seja superado. Esta mudança não implica em necessidade de alteração estrutural do ordenamento, mas antes de raciocínio, com efeitos imediatos na vida prática.

Com o entendimento proposto, o usufruto não pode ser descaracterizado para a aplicação direta das normas relativas ao direito originário. Daí decorre a quebra de todos os conceitos relativos à noção de aplicabilidade do usufruto recair sobre a coisa, como a do quaseusufruto. Por isso o principal efeito é a identidade jurídica do instituto do usufruto de direito, tornando subsidiárias as normas dirigidas aos institutos que se aplicariam nestes casos no vínculo entre titular e usufrutuário.

Efeito interessante é a evidência do caráter potestativo para a constituição do usufruto. Isto já era claro na caracterização anterior, mas não era algo necessário, com passar-se-á se na adoção do entendimento proposto aqui. Normalmente o usufruto, principalmente aquele que nasce por contrato (lembrando principalmente os contratos de compra e venda de imóveis com constituição do usufruto em favor do vendedor, forma mais cotidiana além da doação com reserva), quem arcar com o ônus é o titular. Antes de tudo, deve ser levada em conta a condição de gravame do usufruto em relação ao titular do direito. Seja qual for a fonte para o usufruto (voluntário ou legal), quem é, a princípio, favorecido é o usufrutuário, sendo sua vontade o principal pressuposto fático, além dos jurídicos antes vistos, para o surgimento do gravame. Em outras palavras, o titular, apesar de estar sujeito, não está vinculado enquanto o usufrutuário não aceitar o usufruto e não o levar à registro, não podendo estar “inadimplente” antes disto. Só

\footnotetext{
${ }^{34}$ DANTAS, Francisco Clementino San Tiago. Programa de Direito Civil III: direito das coisas. $2^{\circ}$. Ed. Rio de Janeiro: Ed. Rio, 1981, p. 348.

${ }^{35}$ MIRANDA, Pontes de. Tratado de Direito Privado: Parte especial; direito das coisas: usufruto. Uso. Habitação. Renda sobre imóvel. Tomo XIX, 2ª ed. Rio de Janeiro: Editor Borsoi, 1957, p. 12.
} 
depois do aceite, isto é, da constituição, nascem os direitos subjetivos ao usufrutuário. Desta feita, em regra todo ônus para a constituição do usufruto deve recair sobre o usufrutuário, não ao titular. Outros efeitos foram apontados no próprio corpo do texto, quando se tratou da superação do direito real e pessoal para a condição do usufruto.

É interessante notar também o papel do usufruto no cotidiano. 0 usufruto, como retenção do direito, como um todo, pela exclusividade do exercício por uma pessoa, seja fático ou parte do direito, representa um freio à circulação de capital. Com a impossibilidade de disposição do usufruto pelo usufrutuário ao titular de maneira que não seja a renúncia, se percebe que este direito é imobilizado, e a finalidade de assistência do usufruto, que existia em Roma, se dissolve na atualidade, onde a circulação de capital é primordial ao consumo exacerbado. 0 direito originário pode até mesmo não possuir utilidade alguma.

Se por um lado, o usufruto é prejudicial ao mercado, de outro é uma salvaguarda à relevância do Direito frente ao mercado. Ora, sem papel econômico e social, o usufruto é por excelência um instituto puramente jurídico. Isto desvincula do Direito Privado o seu papel de controle de mercado e de promotor social pelo Estado, embora sejam estas as razões atribuídas àquele, para passar a representar a disposição, a segurança, e a manifestação da liberdade dos particulares.

\section{REFERÊNCIAS}

ARENDT, Hannah. A condição humana. 10. ed. Rio de Janeiro: Forense Universitária, 2003.

ASSIS, Araken de. Manual de processo de execução. $2^{a}$ ed. São Paulo: Editora Revista dos Tribunais, 1995.

BEVILÀCQUA, Clóvis. Direito das Coisas, vol. 1. 4ª ed. Rio de Janeiro: Revista Forense, 1956.

BURKE, Edmund. Reflection on the Revolution in France. New Haven: Yale University Press.

CARVALHOSA, Modesto. Usufruto de ações ao portador [resposta à Moacyr Amaral Santos]; in: :

Revista dos Tribunais. Vol. 512. São Paulo: Editora Revista dos Tribunais, 1978.

DANTAS, Francisco Clementino San Tiago. Programa de Direito Civil III: direito das coisas. $2^{\circ}$. ed. Rio de Janeiro: Ed. Rio, 1981.

GOMES, Orlando. Usufruto de direito; in: Direito privado: novos aspectos. Rio de Janeiro: Freitas Bastos, 1961. 
MIRANDA, Pontes de. Tratado de Direito Privado: Parte especial; direito das coisas: usufruto. Uso. Habitação. Renda sobre imóvel. Tomo XIX, $2^{\text {a }}$ ed. Rio de Janeiro: Editor Borsoi, 1957.

MONTEIRO, Washington de Barros. Curso de Direito Civil: Direito das coisas. Vol. VI. $12^{\mathrm{a}}$ ed. São Paulo: Saraiva, 1973.

MONTESQUIEU. O espírito das leis. Trad. pt. Cristina Murachco. São Paulo: Martins Fontes, 1993.

NEGRÃO, Theotonio; GOUVÊA, José Roberto F. Código de Processo Civil e legislação processual em vigor. 39 ed. São Paulo: Saraiva, 2007.

PEREIRA, Caio Mário da Silva. Instituições de Direito Civil. Vol. 1. 10 ed. Rio de Janeiro: Forense, 1987

- Instituições de Direito Civil: posse, propriedade, direitos reais de fruição, garantia e aquisição. Vol. IV. 9ª ed. Rio de Janeiro: Forense, 1992.

RIZZARDO, Arnaldo. Contratos, Vol. I. Rio de Janeiro: Aied Ed., 1988.

RODRIGUES, Sílvio. Direito Civil: direito das coisas, v. 5. 27ª ed. São Paulo: Saraiva, 2002.

SANTOS, J. M.Carvalho. Código Civil Brasileiro Interpretado. Vol. IX. $9^{\text {a }}$ ed. Rio de Janeiro: Freitas Bastos, 1958.

SANTOS, Moacyr Amaral. Usufruto de ações ao portador; in: Revista dos Tribunais. Vol. 512. São Paulo: Editora Revista dos Tribunais, 1978.

VENOSA, Sílvio de Salvo. Direito Civil: direitos reais. $3^{\circ}$ ed. São Paulo: Atlas, 2003.

VIANA, Marco Aurélio da Silva. Comentários ao Novo Código Civil. vol. XVI. Rio de Janeiro: Forense, 2003.

Recebido em: 07.06.2013

Correções em: 04.12.2013

Aprovado em: 29.12.2013 